\title{
PENGARUH EKUITAS MEREK TERHADAP KEPUTUSAN PEMBELIAN MOBIL JAGUAR DAN LAND ROVER PADA PT. WAHANA AUTO MANDIRI DI JAKARTA
}

\author{
${ }^{1 *}$ Muhamad Apep Mustofa, ${ }^{2}$ Azhar Affandi \\ 1STIE Hidayatullah, Depok, Jawa Barat, Indonesia \\ ${ }^{2}$ Universitas Pasundan, Bandung, Jawa Barat, Indonesia \\ *apep@stiehidayatullah.ac.id
}

\begin{abstract}
Abstrak
Penelitian ini bertujuan untuk mengetahui pengaruh ekuitas merek terhadap keputusan pembelian pada PT. Wahana Auto Mandiri di Jakarta. Metode yang digunakan adalah explanatory research dengan sampel sebanyak 96 responden. Teknik analisis menggunakan analisis statistik dengan pengujian regresi, korelasi, determinasi dan uji hipotesis. Hasil penelitian ini variabel ekuitas merek diperoleh nilai rata-rata skor sebesar 3,452 dengan kriteria baik. Variabel keputusan pembelian diperoleh nilai rata-rata skor sebesar 3,808 dengan kriteria baik. Ekuitas merek berpengaruh positif dan signifikan terhadap keputusan pembelian dengan nilai persamaan regresi $Y=12,455+0,742 X$, dan nilai koefisien korelasi 0,709 atau memiliki tingkat hubungan yang kuat dengan nilai determinasi 50,3\%. Uji hipotesis diperoleh signifikansi 0,000<0,05.
\end{abstract}

Kata Kunci: Ekuitas Merek, Keputusan Pembelian.

\begin{abstract}
This study aims to determine the effect of brand equity on purchasing decisions at PT. Wahana Auto Mandiri in Jakarta. The method used is explanatory research with a sample of 96 respondents. The analysis technique uses statistical analysis with regression testing, correlation, determination and hypothesis testing. The results of this study, the brand equity variable obtained an average score of 3.452 with good criteria. The purchase decision variable obtained an average score of 3.808 with good criteria. Brand equity has a positive and significant effect on purchasing decisions with the regression equation $Y=12.455+0.742 X$, and a correlation coefficient value of 0.709 or having a strong level of relationship with a determination value of $50.3 \%$. Hypothesis testing obtained a significance of $0.000<0.05$.
\end{abstract}

Keywords: Brand Equity, Purchase Decision. 


\section{PENDAHULUAN}

Ketidakpastian adalah mutlak dalam lingkungan ekonomi bisnis yang sangat dinamis. Oleh karena itu, dalam era globalisasi seperti sekarang, perusahaan dituntut bersaing secara kompetitif dalam hal menciptakan dan mempertahankan konsumen (pelanggan) yang loyal. Salah satunya adalah melalui persaingan antar merek. Perusahaan menyadari merek menjadi faktor penting dalam persaingan dan menjadi asset perusahaan yang paling bernilai.

David A. Aaker menyebutkan model ekuitas merek terdiri dari 5 elemen, Keller (2008:670), yaitu: loyalitas merek (brand loyality), kesadran merek (brand awareness), persepsi kualitas (perceived quality), asosiasi merek (brand associations), dan aset-aset dari hak merek lain dari merek (other proprietary brand assets) karena tujuan dari penelitian ini adalah melihat konsep ekuitas merek dari perspektif pelanggan, sedangkan aset-aset hak milik lain dari merek (other proprietary brand assets) adalah komponen ekuitas merek yang lebih cenderung ditinjau dari perspektif perusahaan. Sehingga pada pembahasan elemen ekuitas merek dalam penelitian ini hanya terdiri dari 4 variabel tersebut diatas.

Loyalitas merek (brand loyalty) merupakan satu ukuran keterkaitan seorang pelanggan pada sebuah merek. Loyalitas merek didasarkan atas perilaku konsisten pelanggan untuk membeli sebuah merek sebagai bentuk proses pembelajaran pelanggan atas kemampuan merek memenuhi kebutuhannya. Selain sebagai bentuk perilaku pembelian yang konsisten, loyalitas merek juga merupakan bentuk sikap positif pelanggan dan komitmen pelanggan terhadap sebuah merek lainnya.

Mobil merek Jaguar dan Range Rover adalah contoh merek yang sudah di kenal masyarakat Indonesia. Mobil merek Jaguar mulai dirintis pada tahun 1935 dan resmi menjadi perusahaan Jaguar Mobil Ltd pada tahun 1945. Awalnya, perusahaan ini dimulai sebagai Swallow Sidecar Company (Perusahaan Sepeda Motor) yang didirikan pada tanggal 4 September 1922 oleh William Walmsley (lahir 1891) dan William Lyons (lahir 1901). Walmsley dan Lyons, mereka adalah dua orang sahabat asal Liverpool, Inggris. Awalnya mereka memulai perusahaan dengan membangun sidecars yang kemudian melekat pada sepeda motor yang direkondisi. Mereka membentuk tim kecil yang akhirnya mulai produksi komersial sidecars. Selama tahun 1930, Swallow Sidecar Company mulai diakui di seluruh Eropa terutama dengan harga mobil yang lebih terjangkau yang diproduksi mereka. Swallow Sidecar Company mulai menjadi terkenal dengan permintaan yang terus meningkat.

Fungsi utama dari sistem kognisi adalah untuk menginterpretasi, membuat masuk akal, dan mengerti aspek tertentu dari pengalaman yang dialami konsumen. Fungsi kedua adalah memproses interpretasi menjadi sebuah task kognitif sepeni mengidentifikasi sasaran dan tujuan dalam mengembangkan dan mengevaluasi pilihan alternatif untuk memenuhi tersebut, memilih alternatif, dan melaksanakan alternatif itu. Besar kecilnya intensitas proses system kognitif berbeda-beda tergantung konsumennya, produknya, atau situasinya. Konsumen tidak selalu melakukan aktifitas kognisi secara ekstensif, dalam beberapa kasus konsumen bahkan tidak banyak berpikir sebelum membeli sebuah produk.

Berdasarkan uraian tersebut, maka penulis tertarik untuk menulis penelitian ilmiah ini yang berjudul "Pengaruh Ekuitas Merek Terhadap Keputusan pembelian Kendaraan Jaguar dan Land Rover Pada PT Wahana Auto Mandiri"

\section{METODE}

Populasi dalam penelitian ini berjumlah 96 responden PT. Wahana Auto Mandiri di Jakarta. Teknik pengambilan sampling dalam penelitian ini adalah sampel jenuh, dimana semua anggota populasi dijadikan sebagai sampel. Dengan demikian sampel dalam penelitian ini sampel yang digunakan berjumlah 96 responden. Jenis penelitian yang dipakai 
adalah asosiatif, dimana tujuannya adalah untuk mengetahui atau mencari keterhubungan antara variabel independen terhadap variabel dependennya. Dalam menganalisis data digunakan uji validitas, uji reliabilitas, analisis regresi linier sederhana, analisis koefisien korelasi, analisis koefisien determinasi dan pengujian hipotesis.
HASIL DAN PEMBAHASAN

\section{Analisis Deskriptif}

Pada pengujian ini digunakan untuk mengetahui skor minimum dan maksimum skor tertinggi, ratting score dan standar deviasi dari masing-masing variabel. Adapun hasilnya sebagai berikut:

\begin{tabular}{|c|c|c|c|c|c|}
\hline \multicolumn{6}{|c|}{$\begin{array}{c}\text { Tabel 1. Hasil Analisis Descriptive Statistics } \\
\text { Descriptive Statistics }\end{array}$} \\
\hline & $\mathrm{N}$ & Minimum & Maximum & Mean & Std. Deviation \\
\hline Ekuitas merek $(\mathrm{X})$ & 96 & 29 & 44 & 34.52 & 3.750 \\
\hline Keputusan pembelian (Y) & 96 & 29 & 49 & 38.08 & 3.927 \\
\hline Valid N (listwise) & 96 & & & & \\
\hline
\end{tabular}

Ekuitas merek diperoleh varians minimum sebesar 29 dan varians maximum 44 dengan ratting score sebesar 3,452 dengan standar deviasi 3,750 . Skor ini termasuk pada rentang sakala 3,40 - 4,19 dengan kriteria baik atau setuju.

Keputusan pembelian diperoleh varians minimum sebesar 29 dan varians maximum 49 dengan ratting score sebesar 3,808 dengan standar deviasi 4,009 . Skor ini termasuk pada rentang sakala 3,40 - 4,19 dengan kriteria baik atau setuju.

\section{Analisis Verifikatif}

Pada analisis ini dimaksudkan untuk mengetahui pengaruh variabel independen terhadap variabel dependen. Adapun hasil pengujian sebagai berikut:

a. Analisis Regresi Linier Sederhana

Uji regresi ini dimaksudkan untuk mengetahui perubahan variabel dependen jika variabel independen mengalami perubahan. Adapun hasil pengujiannya sebagai berikut:

\begin{tabular}{|c|c|c|c|c|c|}
\hline \multirow[b]{3}{*}{ Model } & \multicolumn{3}{|c|}{ Coefficients ${ }^{a}$} & \multirow[b]{3}{*}{$\mathrm{t}$} & \multirow[b]{3}{*}{ Sig. } \\
\hline & \multicolumn{2}{|c|}{ Unstandardized Coefficients } & \multirow{2}{*}{$\begin{array}{c}\text { Standardized Coefficients } \\
\text { Beta }\end{array}$} & & \\
\hline & B & Std. Error & & & \\
\hline 1 (Constant) & 12.455 & 2.645 & & 4.708 & .000 \\
\hline Ekuitas merek (X) & .742 & .076 & .709 & 9.744 & .000 \\
\hline
\end{tabular}

$\begin{aligned} & \text { Berdasarkan hasil pengujian } \\ & \text { pada tabel di atas, diperoleh }\end{aligned}$
persamaan regresi $\mathrm{Y}=12,455+$
0,742X. Dari persamaan tersebut
dijelaskan sebagai berikut:
1) Konstanta sebesar 12,455 diartikan
jika ekuitas merek tidak ada, maka
telah terdapat nilai keputusan
pembelian sebesar 12,455 point.
2) Koefisien regresi ekuitas merek
sebesar 0,742, angka ini positif
artinya setiap ada peningkatan

ekuitas merek sebesar 0,742 point maka keputusan pembelian juga akan mengalami peningkatan sebesar 0,742 point.

\section{b. Analisis Koefisien Korelasi}

Analisis koefisien korelasi dimaksudkan untuk mengetahui tingkat kekuatan hubungan dari variabel independen terhadap variabel dependen. Adapun hasil pengujian sebagai berikut: 
Tabel 3. Hasil Pengujian Koefisien Korelasi Ekuitas merek Terhadap Keputusan pembelian.

Correlations $^{b}$

\begin{tabular}{|c|c|c|c|}
\hline & & Ekuitas merek (X1) & Keputusan pembelian $(\mathrm{Y})$ \\
\hline \multirow[t]{2}{*}{ Ekuitas merek $(\mathrm{X})$} & Pearson Correlation & 1 & $.709^{* \star}$ \\
\hline & Sig. (2-tailed) & & .000 \\
\hline \multirow[t]{2}{*}{ Keputusan pembelian $(\mathrm{Y})$} & Pearson Correlation & $.709^{* *}$ & 1 \\
\hline & Sig. (2-tailed) & .000 & \\
\hline
\end{tabular}

Berdasarkan hasil pengujian diperoleh nilai korelasi sebesar 0,709 artinya ekuitas merek memiliki hubungan yang kuat terhadap keputusan pembelian.

\section{c. Analisis Koefisien Determinasi}

Analisis koefisien determinasi dimaksudkan untuk mengetahui besarnya persentase pengaruh dari variabel independen terhadap variabel dependen. Adapun hasil pengujian sebagai berikut:

Tabel 4. Hasil Pengujian Koefisien Determinasi Ekuitas merek Terhadap Keputusan pembelian.

\section{Model Summary}

\begin{tabular}{lr|r|r|r} 
Model & R & R Square & Adjusted R Square & Std. Error of the Estimate \\
\hline 1 & $.709^{a}$ & .503 & .497 & 2.785 \\
\hline
\end{tabular}

Berdasarkan hasil pengujian diperoleh nilai determinasi sebesar 0,503 artinya ekuitas merek memiliki kontribusi pengaruh sebesar 50,3\% terhadap keputusan pembelian, sedangkan sisanya sebesar $49,7 \%$ dipengaruhi oleh faktor lain yang tidak dilakukan penelitian.

\section{d. Uji Hipotesis}

Pengujian hipotesis dengan uji $\mathrm{t}$ digunakan untuk mengetahui hipotesis mana yang diterima.

Rumusan hipotesis: Terdapat pengaruh yang signifikan antara ekuitas merek terhadap keputusan pembelian.

Tabel 5. Hasil Uji Hipotesis Ekuitas merek Terhadap Keputusan pembelian.

\section{Coefficients ${ }^{a}$}

Unstandardized Coefficients Standardized Coefficients

\begin{tabular}{|c|c|c|c|c|c|}
\hline Model & B & Std. Error & Beta & $\mathrm{t}$ & Sig. \\
\hline 1 (Constant) & 12.455 & 2.645 & & 4.708 & .000 \\
\hline Ekuitas merek $(X)$ & .742 & .076 & .709 & 9.744 & .000 \\
\hline
\end{tabular}

Berdasarkan hasil pengujian pada tabel di atas, diperoleh nilai $\mathrm{t}$ hitung $>\mathrm{t}$ tabel atau $(9,744>1,986)$, dengan demikian hipotesis yang diajukan bahwa terdapat pengaruh yang signifikan atara ekuitas merek terhadap keputusan pembelian diterima.

\section{PEMBAHASAN HASIL PENELITIAN}

1. Kondisi Jawaban Responden Variabel Ekuitas merek

Berdasarkan jawaban responden, variabel ekuitas merek diperoleh ratting score sebesar 3,452 berada di rentang skala 3,40 - 4,19 dengan kriteria baik atau setuju.

2. Kondisi Jawaban Responden Variabel Keputusan pembelian

Berdasarkan jawaban responden, variabel keputusan pembelian diperoleh ratting score sebesar 3,808 berada di rentang skala 3,40 - 4,19 dengan kriteria baik atau setuju.

3. Pengaruh Ekuitas merek Terhadap Keputusan pembelian

Ekuitas merek berpengaruh signifikan terhadap keputusan 
pembelian dengan persamaan regresi $Y$ $=12,455+0,742 X$, nilai korelasi sebesar 0,709 atau memiliki hubungan yang kuat dengan kontribusi pengaruh sebesar $50,3 \%$. Pengujian hipotesis diperoleh nilai t hitung $>\mathrm{t}$ tabel atau $(9,744>1,986)$. Dengan demikian hipotesis yang diajukan bahwa terdapat berpengaruh signifikan antara ekuitas merek terhadap keputusan pembelian diterima.

\section{PENUTUP}

\section{Simpulan}

1. Variabel ekuitas merek diperoleh ratting score sebesar 3,452 berada di rentang skala 3,40 - 4,19 dengan kriteria baik atau setuju.

2. Variabel keputusan pembelian diperoleh ratting score sebesar 3,808 berada di rentang skala 3,40 - 4,19 dengan kriteria baik atau setuju.

3. Ekuitas merek berpengaruh signifikan terhadap keputusan pembelian dengan persamaan regresi $\mathrm{Y}=12,455+0,742 \mathrm{X}$, nilai korelasi sebesar 0,709 atau kuat dan kontribusi pengaruh sebesar 50,3\% sedangkan sisanya sebesar 49,7\% dipengaruhi faktor lain. Uji hipotesis diperoleh nilai $\mathrm{t}$ hitung $>\mathrm{t}$ tabel atau $(9,744>1,986)$.

\section{Saran}

1. Sebaiknya untuk Ekuitas Merek pada PT. Wahana Auto Mandiri lebih memfokuskan tampilan desain yang dijual dan lebih memberikan kualitas yang lebih baik.

2. Meskipun sebagian besar responden merasa puas atas Ekuitas Merek pada PT. Wahana Auto Mandiri, namun masih ada skor atau penilaian yang rendah yaitu karyawan masih belum memberikan informasi yang akurat kepada konsumen, karyawan masih kurang menguasai produk knowledge. Pada skor-skor ini perlu dilakukan langkah-langkah perbaikan sehingga diharapkan dapat meningkatnya keputusan pembelian secara menyeluruh.
DAFTAR PUSTAKA

Aaker, A. David. "Manajemen Ekuitas Merek Alih bahasa oleh Aris Ananda", Jakarta: Mitra Utama. 2008.

Agus Purwanto, Erwan dan Dyah Ratih Sulistyastuti, "Metode Penelitian Kuantitatif, Untuk Administrasi Publik, Dan Masalah-masalah Sosial", Yogyakarta: Gaya Media. 2007.

Ahidin, Umar, "Riset pemasaran dan bisnis", Jakarta: Gramedia Pustaka Utama, 2010.

Algifari. (2015). “Analisis Regresi untuk Bisnis dan Ekonomi". Yogyakarta: BPFE.

Alma, Buchari. "Manajemen Pemasaran dan Pemasaran Jasa", Bandung: Alfabeta. 2013.

Arikunto, Suharsimi (2014). "Prosedur Penelitian Suatu Pendekatan Praktek". Jakarta: Rineka Cipta.

Arikunto. "Prosedur Penelitian: Suatu Pendekatan Praktek", Jakarta: Rineka Cipta. 2010.

Ariyanto, A., Nuryani, A., \& Sunarsi, D. (2020). Pengaruh Store Atmosphere Dan Promosi Terhadap Keputusan Pembelian Pada Alfamart BSD Tangerang Selatan. Jurnal Ekonomi Efektif, 3(1).

Bashu Swastha dan T. Handoko (2015) Manajemen Pemasaran Moderen, Yogyakarta: BPFE.

Basu Swastha Dharmmesta. (2014). Manajemen Pemasaran. BPFE: Yogyakarta. Buchari Alma. 2014. Manajemen pemasaran dan Pemasaran Jasa. Edisi Revisi.

Bilson Simamora (2016) Panduan Riset Prilaku Konsumen, Jakarta: PT. Gramedia Pustaka.

Fandy Tjiptono (2017), Serivce Quality and Satisfiation. Jakarta: Edisi tiga. Andi.

Freddy Rangkuti (2016) Strategi Promosi Yang Kreatif, Edisi Pertama, Cetakan Pertama Jakarta: Gramedia Pustaka Utama.

George Terry R \& Rue, Leslie W. Rue (2016) Dasar-Dasar Manajemen, Jakarta Bumi Aksara.

Imam Ghozali (2017). "Aplikasi Analisis Multivariate Dengan Program SPSS". 
Edisi Kelima. Semarang: Badan Penerbit Undip.

Irmal, I., Gustiarani, E., \& Sunarsi, D. (2020). Pengaruh E-Marketing dan E-CRM terhadap E-Loyalty Pengunjung Situs Website www. Cangkirbogor. com. Jurnal Ekonomi Efektif, 2(2).

J. Setiadi, Nugroho, SE., MM., "Perilaku Konsumen Konsep dan Implikasi untuk Strategi dan Penelitian Pemasaran", Jakarta: Kencana. 2003.

Jasmani, J., \& Sunarsi, D. (2020). The Influence of Product Mix, Promotion Mix and Brand Image on Consumer Purchasing Decisions of Sari Roti Products in South Tangerang. PINISI Discretion Review, 1(1), 165-174.

Mani, J. (2017). Pengaruh Persepsi Merek Dan Kualitas Pelayanan Terhadap Kepuasan Pelanggan (Studi Kasus Pada PT. Bisma Narendra Di Jakarta). Jurnal Mandiri, 1(2), 187-206.

Mani, J. (2018). Pengaruh Peran Nilai Pelanggan Dan Citra Merek Terhadap Kinerja Pemasaran. Jurnal Mandiri, 2(2), 263-280.

Mulyadi, "Manajemen pemasaran", Edisi Ketiga, Cetakan Ketiga, Penerbit Jakarta: Salemba Empat. 2001.

Rangkuti, Freddy, "Analisis SWOT Teknik Membedah Kasus Bisnis", Jakarta : Penerbit PT. Gramedia Pustaka Utama . 2014.

Rao, Purba, (2012). "Measuring Consumer Perceptions Through Factor Analysis", The Asian.

S. A. Surachman, "Dasar-Dasar Manajemen Merek", Malang: Bayumedia Publishing. 2008.

Santoso, Singgih (2015). “Menguasai Statistik Multivariat". Jakarta: PT Elex Media Komputindo.

Y Kadarusman, D Sunarsi. (2020). Pengaruh Strategi Penetapan Harga Terhadap Peningkatan Jumlah Siswa Pada SMK PGRI Balaraja. JS (JURNAL SEKOLAH) 4 (3), 213-221
Sarwani, S., Akbar, I. R. ., Handoko, A. L. ., \& Ilham, D. . (2020). Pengaruh Pelatihan dan Motivasi terhadap Produktivitas Kerja Karyawan pada PT. Lion Mentari Airlines Bandara Internasional Soekarno Hatta Cengkareng. Jurnal Ilmu Komputer Dan Bisnis, 11(2a), 91-100. https://doi.org/10.47927/jikb.v11i2a .24

Setiadi, Nugroho J, "Perilaku Konsumen", Jakarta: Kencana. 2010

Siregar, Sofyan, "Statistika Deskriptif untuk penelitian", Jakarta: Rajawali Pers. 2010.

Sudjana (2014) "Metode Statistika", Bandung: Tarsido.

Sugiyono (2017), "Metode Penelitian Administrasi : dilengkapi dengan Metode $R \mathcal{E} D^{\prime \prime}$. Bandung: Alfabeta.

Suhartanto (2014). "Metode Riset Pemasaran". Bandung: Alfabeta

Sunarsi, D. (2020). Pengaruh Bauran Pemasaran Dan Kualitas Pelayanan Terhadap Kepuasan Konsumen Pada Giant Dept Store Cabang BSD Tangerang. E-Mabis: Jurnal Ekonomi Manajemen dan Bisnis, 21(1).

Supardi. "Manajemen pemasaran", Jakarta: Raja Grafindo Persada. 2014.

$\mathrm{T}$ Triyadi, U Ahidin, J Jasmani - Jurnal Manajemen, Bisnis dan Organisasi (JUMBO), 2019. Pengaruh Promosi Dan Kualitas Pelayanan Terhadap Kepuasan Pelanggan Pada PT. Surya Karya Prima Di Jakarta.

Ukkas, I., \& Iksan, M. (2017). Empowering Business Group Peanut Tenteng. Proceeding International Conference on Natural and Social Science (ICONSS) 2017, 1(1), Article 1.https://journal.uncp.ac.id/index.p $\mathrm{hp} /$ iconss/article/view/54

Yusuf, A., \& Sunarsi, D. (2020). The Effect of Promotion and Price on Purchase Decisions. Almana: Jurnal Manajemen dan Bisnis, 4(2), 272-279. 